\title{
Effect of Addition of Alccofine on the Compressive Strength of Cement Mortar Cubes
}

\author{
Balamuralikrishnan R. ${ }^{1 *}$, Saravanan J. ${ }^{2}$ \\ ${ }^{I}$ Department of Civil and Environmental Engineering, College of Engineering, National University of Science and Technology, PO \\ Box:2322, CPO Seeb 111, Muscat, Sultanate of Oman \\ ${ }^{2}$ Department of Civil and Structural Engineering, Annamalai University, Pin:608001,Tamilnadu, India
}

\begin{abstract}
In the modern era, many research works are going on throughout the world for finding suitable cementitious material for the replacement of cement since it causes environmental pollution. In this order Fly ash, Silica fume, GGBS, Metakaolin, Micro materials, Quartz powder, etc. are tried out for replacing partially or fully the cement in concrete. A new ultrafine material called Alccofine (AF) which is manufactured from glass wastes is tried out for replacing partially in this research. Compressive strength is one of the important properties of cement. Strength tests are not made on neat cement paste because of difficulties of excessive shrinkage and subsequent cracking of neat cement. Cement mortar of 1:3 mix proportion is used to cast the cubes having an area of $50 \mathrm{~cm} 2$ are used for the determination of compressive strength of cement as per IS: 4031-1988 (Part-6). The graded Indian Standard sand (Ennore Sand -ES) confirming to IS: 650-1991 is used for preparing the cubes. In the same mix proportion, the same size cubes are cast with the River Sand (RS) to study the difference of the compressive strength between the Indian standard sand and river sand. Ordinary Portland cement (OPC) and Portland Pozzolana Cements (PPC) are used. The present study is the influence of Alccofine on cement mortar cubes by replacing the cement by Alccofine with various proportions like 5\%,10\%,15\%,20\% were cast and tested in the laboratory as per Indian Standard 4301-1988 (Part-6) and the results were analysed and presented in the form of charts and graphs. It is observed that the early age strength is obtained for all the combinations but 10 percent of Alccofine yields more strength than other dosages.
\end{abstract}

\section{Keywords:}

Alccofine-1203;

Indian Standard Sand (Ennore Sand);

Compressive Strength;

Mortar Cube;

Ennore Sand.

\section{Article History:}

$\begin{array}{llll}\text { Received: } & 17 & \text { December } & 2020 \\ \text { Revised: } & 28 & \text { February } & 2021 \\ \text { Accepted: } & 08 & \text { March } & 2021 \\ \text { Published: } & 01 & \text { April } & 2021\end{array}$

\section{1- Introduction}

Cement related materials are the most significant construction materials, and it is most likely that they will remain to have the same importance in the forthcoming years. Concrete is characteristically the most immense individual material element in the natural build environment. Concrete contains primarily cement, aggregate and water. Even though cement typically only includes $12 \%$ of the concrete mass, it accounts for approximately $93 \%$ of the total embodied energy of the concrete and 6 to $7 \%$ of the global $\mathrm{CO}_{2}$ emissions. In order to expand the properties of cement/ concrete relative to the environment, cost and strength, their manufacture has been increasingly directed towards blended cements. So a partial replacement of Ordinary Portland Cement and Portland Pozzolana Cement with Alccofine has to be considered well and the change of characters is observed. Compressive strength is one of the significant tests of cement. Strength tests are not made on neat cement paste because of complications of excessive shrinkage and succeeding cracking of neat cement paste. In this work the impact of Alccofine replacement on the mechanical properties of cement mortar cubes is studied

* CONTACT: Balamuralikrishnan@nu.edu.om

DOI: http://dx.doi.org/10.28991/esj-2021-01265

(C) 2021 by the authors. Licensee ESJ, Italy. This is an open access article under the terms and conditions of the Creative Commons Attribution (CC-BY) license (https://creativecommons.org/licenses/by/4.0/). 
If the advantages of Alccofine 1203 are detected in the concrete mix design, the initial rate of strength development was found to be increased or similar as that of Silica Fume [1]. These industrial by-products such as fly ash, GGBS, rice husk ash, alccofine 1203, silica fume, and metakaolin require a massive area of land for their safe disposal [2]. Pozzolanic concretes are widely used throughout the world where oil, gas, nuclear and power industries are among the major users. The applications of such concretes are increasing day by day due to their superior structural performance, environmental friendliness, and energy conserving implications. Cement - based material is among the most important construction materials, and it is most likely that they will continue to have importance in the future. However, these construction and engineering materials must meet new and higher demands, these construction materials such as GGBS, SF, AL, and FA etc. GGBS and AL used as Supplementary Cementitious Materials (SCM). When pozzolanic materials are united to concrete, the GGBS present in these materials react with the calcium hydroxide released during the hydration of cement and forms additional C-S-H gel which improves the durability and the mechanical properties of concrete. Durable concrete will retain its original form quality, and serviceability when exposed to the environment. The inclination of the construction industry to use sustainable materials in producing a more benign concrete is gaining popularity. In addition to this, economic viability along with performance plays a key role in the contemporary research work on various new alternatives and substitutes [3]. By using Alccofine we can reduce the construction industry's contributions towards global warming and at the same time, utilize an accumulated amount of industrial by-product in the correct mechanism and the concrete industry can overcome these deficits and achieve concrete that is stronger and lasts longer [4].

The use of new techniques and methodology in making construction more and more self-efficient and reliable is the hot topic among various researchers now-a-days. To quench the thirst of strength, durability and hence sustainability, high strength and high performance concrete was once developed in order to fulfill the unanimous demands. The use of micro-fillers came into existence by this very concept only [5]. Alccofine 1203 can also be utilized as a high range water reducer to improve compressive strength or as a super workability aid to improve flow [6]. Mechanical properties of concrete which includes compressive strength and pull out strength. Compression test is the most common test conducted on hardened concrete partly because it is an easy test to perform and partly because most of the desirable characteristics properties of concrete are qualitatively related to its compressive strength [7]. Compressive strength of concrete is important because of the main properties of concrete. Compressive test is the most common test conducted on the hardened concrete because it is an easy test to perform and most of the desirable characteristic properties of concrete are qualitatively related to its compressive strength. The effect of ultra-fine slag (Alccofine) replacement on the mechanical properties of high strength concrete is studied. It has been found that use of ultra-fine slag not only improves the compressive strength of concrete but also improves the workability and fluidity of the mix [8].

It has been found that use of Alccofine improves the compressive strength of cement. The effect of pozzolanic admixture on compressive strength of HPC Concrete, were more efficient than the conventional steel building when using the Alccofine in PEB Buildings [9]. Normally 15\% cement replacement with Alccofine gives optimum strength and workability for Binary Blended Concrete [10]. Flexural strength of beams with 22\% of Fly Ash and $8 \%$ of Alccofine provided highest compressive strength of $78.58 \mathrm{~N} / \mathrm{mm}^{2}$ and got maximum flexural strength of $7.02 \mathrm{MPa}$ in mix at $20 \%$ Fly ash and $10 \%$ Alccofine [11].

The compressive strength test was carried out on the standard size specimen cubes in water binder ratio as 0.45 and 0.5 . From the results it is found that the maximum compressive strength of concrete is achieved by using Alccofine $10 \%$ and Fly Ash 30\% [12]. The compressive strength of concrete with blend containing 59\% Cement 15\% Metakaolin and $26 \%$ Alccofine has achieved maximum packing density and also the flexural strength of the beam has increased with the increases in the percentage of Alccofine [13]. Various tests are carried out such as, compressive strength tests, chloride resistance test, Sea water test, Rapid chloride penetration test and Acceleration corrosion test, were conducted with Alccofine is varies from $4 \%$ to $14 \%$ and Fly Ash varies from $20 \%$ to $35 \%$ and the water binder ratio (w/b) adopted was 0.30 and super plasticizer was estimated as $1 \%$ of weight of binder. From the results it is concluded that the compressive strength achieved by using Alccofine $8 \%+20 \%$ Fly ash is $72.97 \mathrm{MPa}$ in 56 days and due to its more compactness and less permeability of concrete effect of chloride attack is reducing and weight loss of the steel in the Alccofine is less [14]. The deterioration of reinforced concrete structures usually comprises the transport of aggressive substances from the surrounding environment followed by physical and chemical actions in its internal structure [15]. The use of these industrial waste in concrete could reduce waste in the environment as well helps the environment against pollution as it is known that one ton of cement manufacture released one ton of carbon dioxide to the environment. Alccofine is a new replacement material on which very limited research has been done so far [16]. The literature review helps to confine the present study objectives and scope which are given as follows.

\section{Objectives and Scope}

- To determine the strength of OPC and PPC with Alccofine with various percentages.

- To design the mix proportion for Alccofine 1203 partially replacing the OPC-43 grade and PPC cement in various percentages such as 5, 10, 15 and $20 \%$. 
- To determine the compressive strength of the cement mortar of the partially replaced Alccofine 1203 in OPC and PPC.

- To conduct tests for strength with the mortar cubes made by using Alccofine in combination with OPC and PPC.

- To compare the experimental results with codal values.

\section{1-2-Alccofine}

Alccofine is a micro fine material. Use Ground granulated blast- furnace slag is a non-metallic product consisting essentially of silicates and aluminates of calcium and other bases. The molten slag is rapidly chilled by quenching in water to form a glassy sand like granular material. The granulated material when further ground to less than 45 microns will have a specific surface of about 400 to $600 \mathrm{~m}^{2} / \mathrm{kg}$. Alccofine is a well graded particle size smaller than cement and higher than Micro Silica. It is generally considered that the fineness of cement or and cementitious materials have an influence on strength. Use of Alccofine enhances the performance of concrete in terms of durability due to its superior particle size distribution. Alccofine has particle range 0.1 to 17 microns, average particle size is 4 microns.

\section{1-3-Alccofine-1203}

Alccofine-1203 is a specially treated product based on high glass content with high reactivity obtained through the process of controlled granulation. The raw materials are composed of low calcium silicates. The processing with other selected ingredients results in controlled particle size distribution (PSD). The computed blain value based on PSD is around $12000 \mathrm{~cm}^{2} / \mathrm{gm}$ and is truly ultra-fine. Due its unique chemistry and ultrafine particle size, Alccofine-1203 provides reduced water demand for given workability, even up to $70 \%$ replacement level as per requirement of concrete performance. Alccofine 1203 can also be used as a high range water reducer to improve compressive strength or as a super workability aid to improve flow.

\section{1-3-1- Properties of Alccofine-1203}

$\begin{array}{rll}\text { Physical analysis } & \text { Range } \\ \text { - } & \text { Bulk Density } & 600-700 \mathrm{~kg} / \mathrm{m}^{3} \\ \text { - } & \text { Surface Area } & 12000 \mathrm{~cm}^{2} / \mathrm{gm} \\ \text { - } & \text { Particle shape } & \text { Irregular } \\ \text { - } & \text { Particle size-d 10 } & <2 \mathrm{um} \\ \text { - } \mathrm{d}_{50} & <5 \mathrm{um} \\ \text { - } \mathrm{d}_{90} & <9 \mathrm{um}\end{array}$

\section{Chemical composition}

- Calcium oxide: $-34 \%$

- $\quad$ Silicon dioxide: $-35 \%$

- Aluminum dioxide:-24\%

\section{2- Experimental Investigations}

\section{2-1- Alccofine -1203}

Alccofine-1203 (Figure 1) is the unique chemical composition mainly of $\mathrm{CaO} 30-34 \%$ and $\mathrm{SiO}_{2} 30-36 \%$. The chemical composition is shown in Table 1 .
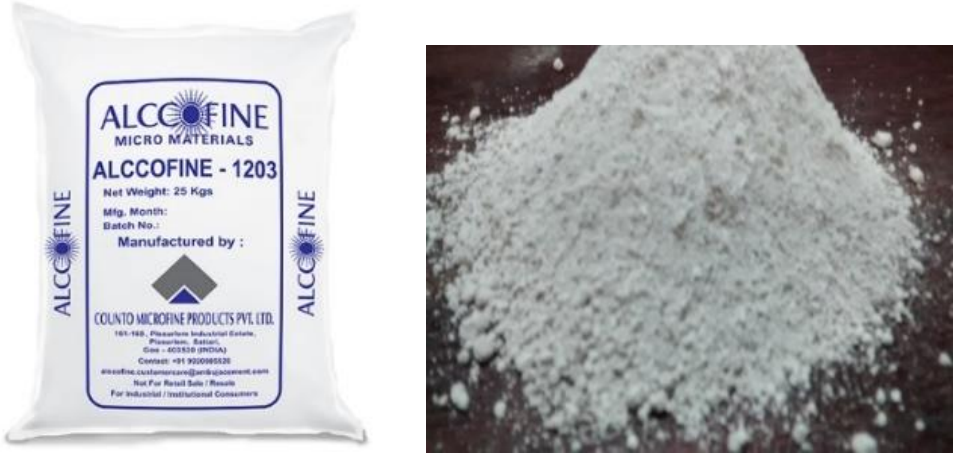

Figure 1. Alccofine 1203. 
Table 1. Chemical composition of Alccofine-1203.

\begin{tabular}{cc}
\hline Chemical Analysis & Mass \% \\
\hline $\mathrm{CaO}$ & 33 \\
$\mathrm{Al}_{2} \mathrm{O}_{3}$ & 22.1 \\
$\mathrm{Fe}_{2} \mathrm{O}_{3}$ & 2.1 \\
$\mathrm{SO}_{3}$ & 0.3 \\
$\mathrm{MgO}$ & 7.5 \\
$\mathrm{SiO}_{2}$ & 35 \\
\hline
\end{tabular}

\section{2-2- Fine Aggregate}

The fine aggregate available naturally from river beds is used as per IS 383-1970 Code conforming that, it is coming under Zone II and also the Indian standard sand (Ennore sand) is as per the IS 650 - 1991 code conforming was used [17].

\section{2-3-Water}

Portable water was used for mixing cement mortar and curing the specimens.

\section{2-4- Cement Mortar}

Two types of cement were used this study say Ordinary Portland Cement 43 grade and Portland Pozzolana Cement. The physical properties and tests of cement was carried out as per IS: 8112-1989 and IS 1489 (part- I) 1991 [18]. After casting the specimens need to be allowed to cure in real environmental conditions for about 28 days. The strength of the mortar cubes under axial compression is determined by loading on a standard mortar cube of size $7.06 \times 7.06 \times 7.06 \mathrm{~cm}$.

\section{2-5- Mix Proportions}

As by IS: 4031(part 6) 1988, to determining the strength of cement as represented by compressive strength tests on mortar cubes, the mix proportion is taken as 1:3, in that Alccofine 1203 is replaced partially in cement by ratio (5\%, $10 \%, 15 \%, 20 \%)$ is initially mixed and was cast in a standard $7.06 \mathrm{~cm} \mathrm{x} 7.06 \mathrm{~cm} \times 7.06 \mathrm{~cm}$ cube. The material for each cube was mixed separately and the quantity of cement, sand and water as follows. Cement-200g, Sand-600gm, Water$(\mathrm{P} / 4+3.0)$ percent of combined mass of cement and sand. Then it was removed from mould and cured. Then the cubes were removed from curing, wipe cleaned and tested. The detailed experimental programme is shown in Figure 2.

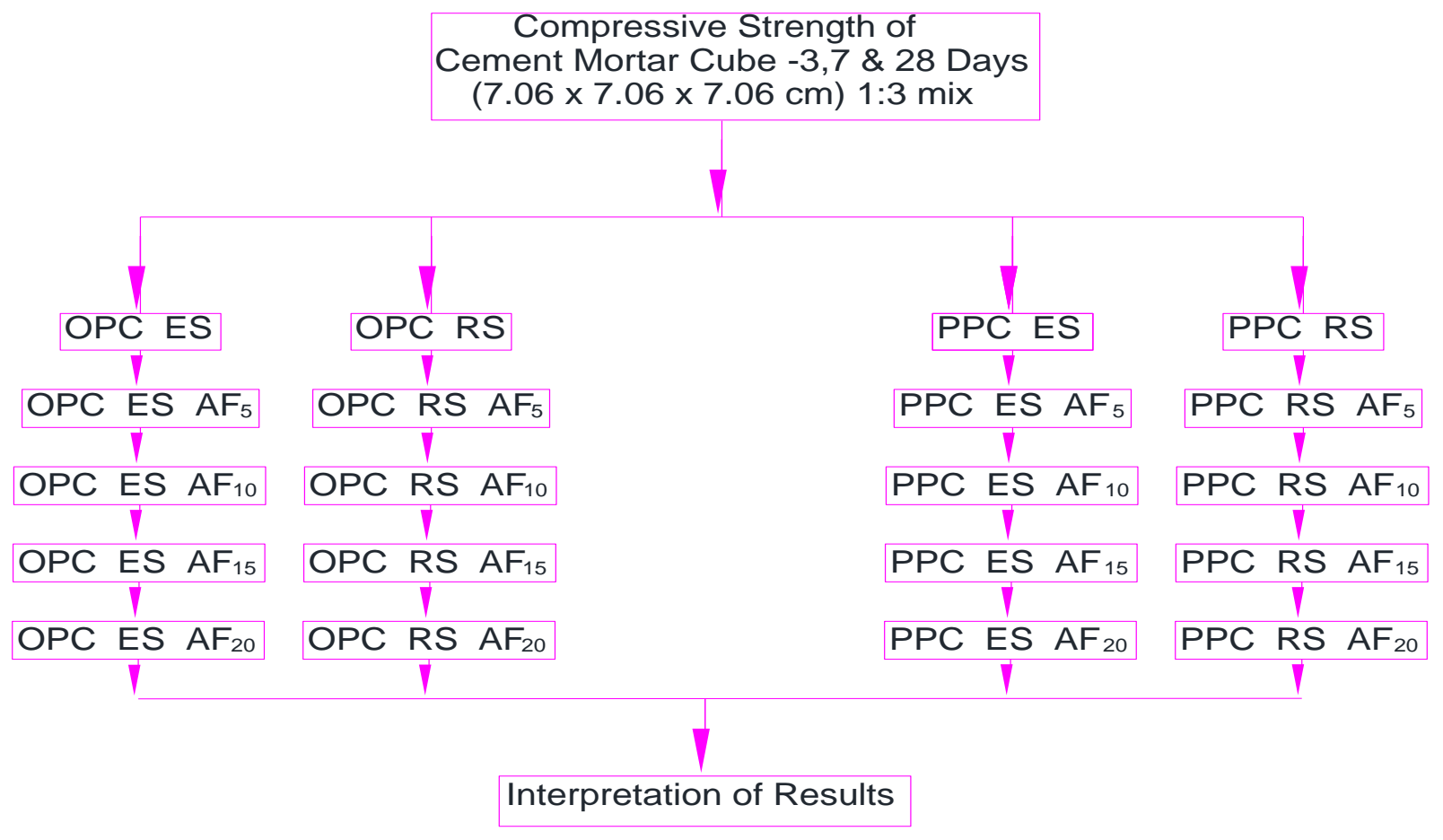

Figure 2. Experimental programme. 
The calculation of ten mix proportions (Mix 1 to Mix 10):

Mix-1: OPC, both ES and RS:

$(\mathrm{P} / 4+3) \%$ mass of cement and sand

$(27.5 / 4+3) 800 / 100=79 \mathrm{ml}$

Mix-2: PPC, both ES and RS:

$(\mathrm{P} / 4+3) \%$ mass of cement and sand

$(34 / 4+3) 800 / 100=92 \mathrm{ml}$

Mix- 3: OPC ES (RS) AF5:

OPC Consistency 27.5

Alccofine Consistency 48.5

$(28.5 / 4+3) 800 / 100=81 \mathrm{ml}$

Mix- 4: OPC ES (RS) AF10:

$\begin{array}{ll}\text { OPC } & \text { Consistency } 27.5 \\ \text { Alccofine } & \text { Consistency } 48.5\end{array}$

$(29.60 / 4+3) 800 / 100=83.20 \mathrm{ml}$

Mix- 5: OPC ES (RS) AF15:

OPC Consistency 27.5

Alccofine

Consistency 48.5

$(30.65 / 4+3) 800 / 100=85.30 \mathrm{ml}$

Mix- 6: OPC ES (RS) AF20:

OPC Consistency 27.5

Alccofine

Consistency 48.5

$(31.70 / 4+3) 800 / 100=87.40 \mathrm{ml}$

Mix - 7: PPC ES (RS) AF5:

Alccofine

Consistency 48.5

$(34.725 / 4+3) 800 / 100=93.45 \mathrm{ml}$

Mix- 8: PPC ES (RS) AF10:

PPC Consistency $34 \quad(90 \%)$

Alccofine Consistency 48.5

$(35.45 / 4+3) 800 / 100=94.90 \mathrm{ml}$

Mix- 9: PPC ES (RS) AF15:

\begin{tabular}{|c|c|c|c|c|}
\hline OPC & Consistency 34 & $(85 \%)$ & 28.9 & $170 \mathrm{gm}$ \\
\hline Alccofine & Consistency 48.5 & $(15 \%)$ & $\begin{array}{l}7.275 \\
36175\end{array}$ & $30 \mathrm{gm}$ \\
\hline \multicolumn{5}{|c|}{$(36.175 / 4+3) 800 / 100=96.35 \mathrm{ml}$} \\
\hline \multicolumn{5}{|c|}{ Mix- 10: PPC ES (RS) AF20: } \\
\hline OPC & Consistency 34 & $(80 \%)$ & 27.20 & $160 \mathrm{gm}$ \\
\hline \multirow[t]{2}{*}{ Alccofine } & Consistency 48.5 & $(20 \%)$ & 9.70 & $40 \mathrm{gm}$ \\
\hline & & & 36.90 & $200 \mathrm{gm}$ \\
\hline
\end{tabular}

$\begin{array}{lll}(95 \%) & 26.125 & 190 \mathrm{gm} \\ (5 \%) & 2.425 & 10 \mathrm{gm} \\ & 28.5 & 200 \mathrm{gm}\end{array}$

$\begin{array}{lll}(90 \%) & 24.75 & 180 \mathrm{gm} \\ (10 \%) & 4.85 & 20 \mathrm{gm} \\ & 29.60 & 200 \mathrm{gm}\end{array}$

$(85 \%)$

23.375

7.275

30.65

$170 \mathrm{gm}$

$30 \mathrm{gm}$

$200 \mathrm{gm}$

$\begin{array}{lll}(80 \%) & 22.0 & 160 \mathrm{gm} \\ (20 \%) & 9.70 & 40 \mathrm{gm} \\ & 31.70 & 200 \mathrm{gm}\end{array}$

$\begin{array}{lll}(95 \%) & 32.3 & 190 \mathrm{gm} \\ (5 \%) & 2.425 & 10 \mathrm{gm} \\ & 34.725 & 200 \mathrm{gm}\end{array}$

PPC Consistency 34

$(36.90 / 4+3) 800 / 100=97.80 \mathrm{ml}$

\section{2-6- Laboratory Tests on Materials}

2.

The specific gravity of the materials was determined as per IS 2386-1963 [19]. The values are presented in the Table 
Table 2. Specific gravity of different materials.

\begin{tabular}{ccc}
\hline Sl. No & Description & Specific Gravity \\
\hline 1 & OPC Cement & 3.01 \\
2 & PPC Cement & 3.07 \\
3 & Alccofine & 2.84 \\
4 & Ennore Sand & 2.64 \\
5 & River Sand & 2.61 \\
\hline
\end{tabular}

Sieve Analysis Fine aggregate confirming to grading zone - III of Table 3 of IS: 383:1970 and fineness modulus 2.23.

Table 3. Sieve Analysis.

\begin{tabular}{ccc}
\hline Sl. No & $\begin{array}{c}\text { Sieve Size in mm Percentage } \\
\text { of passing }\end{array}$ & Percentage of passing \\
\hline 1 & 4.75 & 99.4 \\
2 & 2.36 & 97.2 \\
3 & 1.18 & 93.6 \\
4 & 600 micron & 76.4 \\
5 & 300 micron & 53.1 \\
6 & 150 micron & 10.3 \\
7 & 75 micron & 0.3 \\
8 & Silt & 0 \\
\hline
\end{tabular}

\section{Indian Standard Sand (Ennore Sand)}

The Indian standard sand confirming to IS 650-1991.As a standard fine aggregate used for assessing the quality of cement, Standard sand plays a very important role in the cement industry. The Standard sand is obtained from Tamil Nadu Minerals Ltd, (TAMIN) at Ennore, Chennai, India. The Standard sand shall 100\% pass through 2 mm IS sieve and shall be $100 \%$ retained on 90 -micron IS sieve (Figure 3 to 5).
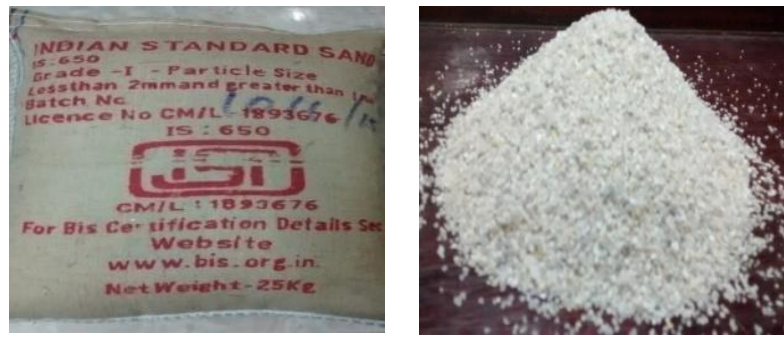

Figure 3. Grade-I: Less than $2 \mathrm{~mm}$ greater than $1 \mathrm{~mm}$.
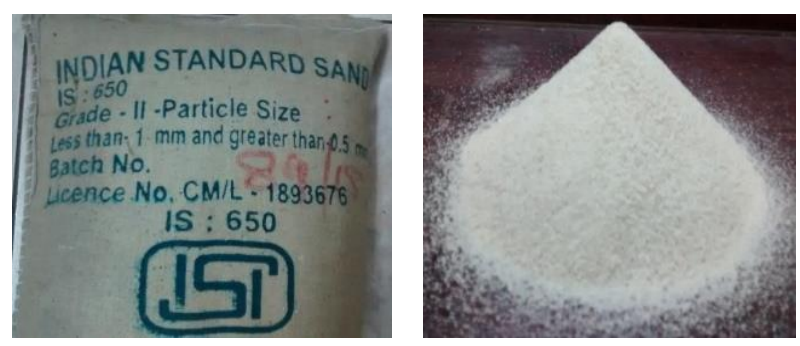

Figure 4. Grade-II: Less than $1 \mathrm{~mm}$ greater than $0.5 \mathrm{~mm}$.
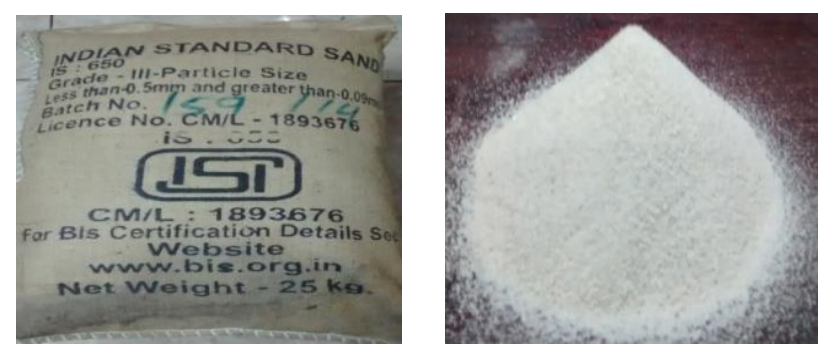

Figure 5. Grade-III: Less than $0.5 \mathrm{~mm}$ greater than $0.09 \mathrm{~mm}$. 


\section{Properties of Indian standard sand (Ennore sand)}

Colour: Grayish white

Shape of Grains: Sub Angular

\section{Chemical properties}

$\mathrm{SiO}_{2}: 99.30 \%$

$\mathrm{Fe}_{2} \mathrm{O}_{3}: 0.10 \%$

\section{Petrography Analysis}

Quartz: 97.40\%

Feldspar: $2.50 \%$

The Standard consistency parameter is used to determine initial setting time and cement compressive strength. The values are presented in Table 3.

Table 4. Normal consistency.

\begin{tabular}{ccc}
\hline Sl. No & Description & Normal consistency \\
\hline 1 & OPC Cement & $27.5 \%$ \\
2 & PPC Cement & $34.0 \%$ \\
3 & Alccofine & $48.5 \%$ \\
\hline
\end{tabular}

The initial setting time of OPC and PPC cement are given in Table 4.

Table 5. Initial setting time.

\begin{tabular}{ccc}
\hline Sl. No & Description & Initial setting time (minutes) \\
\hline 1 & OPC Cement & 70 \\
2 & PPC Cement & 155 \\
3 & Alccofine & 165 \\
\hline
\end{tabular}

The SEM analysis of cement and alccofine 1203 is shown in Figures 6 and 7.

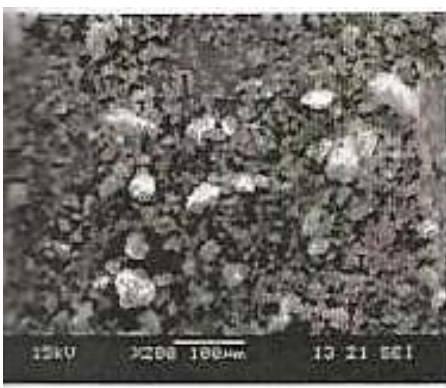

(a) 100 micron

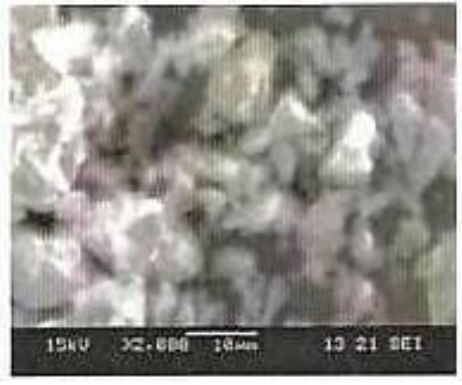

(b) 10 micron

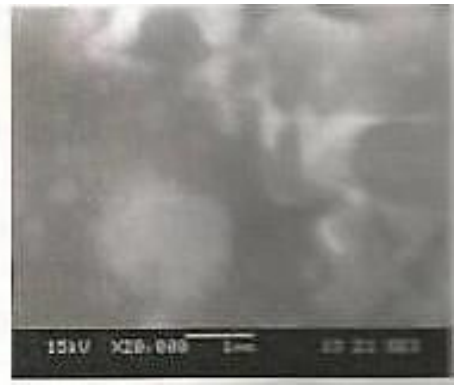

(c) 1 micron

Figure 6. SEM Analysis for various materials (OPC-43).

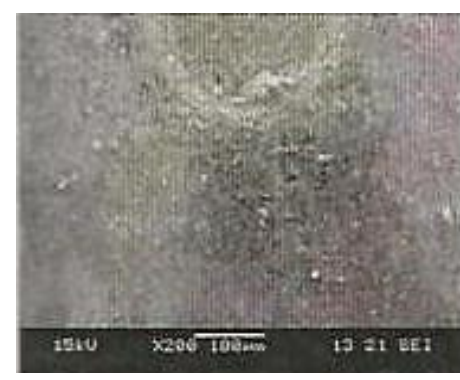

(a) 100 micron

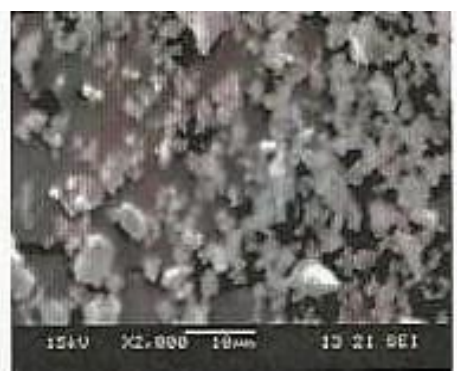

(b) 10 micron

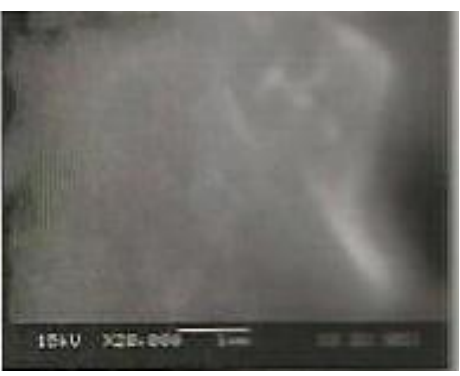

(c) 1 micron

Figure 7. SEM Analysis for various materials (Alccofine 1203). 
Table 6. Mix proportion for cement mortar cubes.

\begin{tabular}{cccccc}
\hline Sl.No. & Designation & Cement $(\%)$ & $\mathbf{F ~ A}$ & Alccofine $(\%)$ & W/B $(\mathrm{ml})$ \\
\hline 1 & OPC ES & 1 & 3 & 0 & 79 \\
2 & OPC RS & 1 & 3 & 0 & 79 \\
3 & PPC ES & 1 & 3 & 0 & 92 \\
4 & PPC RS & 1 & 3 & 0 & 92 \\
5 & OPC ES AF $_{5}$ & 0.95 & 3 & 0.05 & 81 \\
6 & OPC ES AF $_{10}$ & 0.90 & 3 & 0.10 & 83.20 \\
7 & OPC ES AF F $_{15}$ & 0.85 & 3 & 0.15 & 85.30 \\
8 & OPC ES AF $_{20}$ & 0.80 & 3 & 0.20 & 87.40 \\
9 & OPC RS AF $_{5}$ & 0.95 & 3 & 0.05 & 81 \\
10 & OPC RS AF $_{10}$ & 0.90 & 3 & 0.10 & 83.20 \\
11 & OPC RS AF F $_{15}$ & 0.85 & 3 & 0.15 & 85.30 \\
12 & OPC RS AF $_{20}$ & 0.80 & 3 & 0.20 & 87.40 \\
13 & PPC ES AF $_{5}$ & 0.95 & 3 & 0.05 & 93.45 \\
14 & PPC ES AF $_{10}$ & 0.90 & 3 & 0.10 & 94.90 \\
15 & PPC ES AF F $_{15}$ & 0.85 & 3 & 0.15 & 96.35 \\
16 & PPC ES AF $_{20}$ & 0.80 & 3 & 0.20 & 97.80 \\
17 & PPC RS AF $_{5}$ & 0.95 & 3 & 0.05 & 93.45 \\
18 & PPC RS AF F $_{10}$ & 0.90 & 3 & 0.10 & 94.90 \\
19 & PPC RS AF F $_{15}$ & 0.85 & 3 & 0.15 & 96.35 \\
20 & PPC RS AF $_{20}$ & 0.80 & 3 & 0.20 & 97.80 \\
\hline
\end{tabular}

Table 7. Details of number of specimens for cement mortar cubes.

\begin{tabular}{|c|c|c|c|c|c|c|}
\hline \multirow{2}{*}{ Sl. No. } & \multirow{2}{*}{ Mix } & \multicolumn{4}{|c|}{ Curing Days } & \multirow{2}{*}{ Total } \\
\hline & & Specimens & 3 Days & 7 Days & 28 Days & \\
\hline 1 & OPC RS & \multirow{20}{*}{ Cubes } & 3 & 3 & 3 & 9 \\
\hline 2 & OPC ES & & 3 & 3 & 3 & 9 \\
\hline 3 & PPC RS & & 3 & 3 & 3 & 9 \\
\hline 4 & PPC ES & & 3 & 3 & 3 & 9 \\
\hline 5 & $\mathrm{OPC} \mathrm{RS} \mathrm{AF}_{5}$ & & 3 & 3 & 3 & 9 \\
\hline 6 & OPC RS AF ${ }_{10}$ & & 3 & 3 & 3 & 9 \\
\hline 7 & OPC RS AF $\mathrm{F}_{15}$ & & 3 & 3 & 3 & 9 \\
\hline 8 & $\mathrm{OPC}$ RS AF $\mathrm{AF}_{20}$ & & 3 & 3 & 3 & 9 \\
\hline 9 & OPC ES AF 5 & & 3 & 3 & 3 & 9 \\
\hline 10 & OPC ES AF ${ }_{10}$ & & 3 & 3 & 3 & 9 \\
\hline 11 & OPC ES AF $\mathrm{AF}_{15}$ & & 3 & 3 & 3 & 9 \\
\hline 12 & OPC ES AF 20 & & 3 & 3 & 3 & 9 \\
\hline 13 & PPC RS $\mathrm{AF}_{5}$ & & 3 & 3 & 3 & 9 \\
\hline 14 & PPC RS AF $\mathrm{AF}_{10}$ & & 3 & 3 & 3 & 9 \\
\hline 15 & PPC RS AF $\mathrm{AF}_{15}$ & & 3 & 3 & 3 & 9 \\
\hline 16 & PPC RS AF 20 & & 3 & 3 & 3 & 9 \\
\hline 17 & $\mathrm{PPC} \mathrm{ES} \mathrm{AF}_{5}$ & & 3 & 3 & 3 & 9 \\
\hline 18 & PPC ES AF 10 & & 3 & 3 & 3 & 9 \\
\hline 19 & PPC ES $\mathrm{AF}_{15}$ & & 3 & 3 & 3 & 9 \\
\hline 20 & PPC ES $\mathrm{AF}_{20}$ & & 3 & 3 & 3 & 9 \\
\hline \multicolumn{6}{|c|}{ Total number of Cubes } & 180 No. \\
\hline
\end{tabular}




\section{2-7- Casting and Curing of Specimens}

The specimen were cast and curing set up are shown in Figures 8 (a, b, and c).
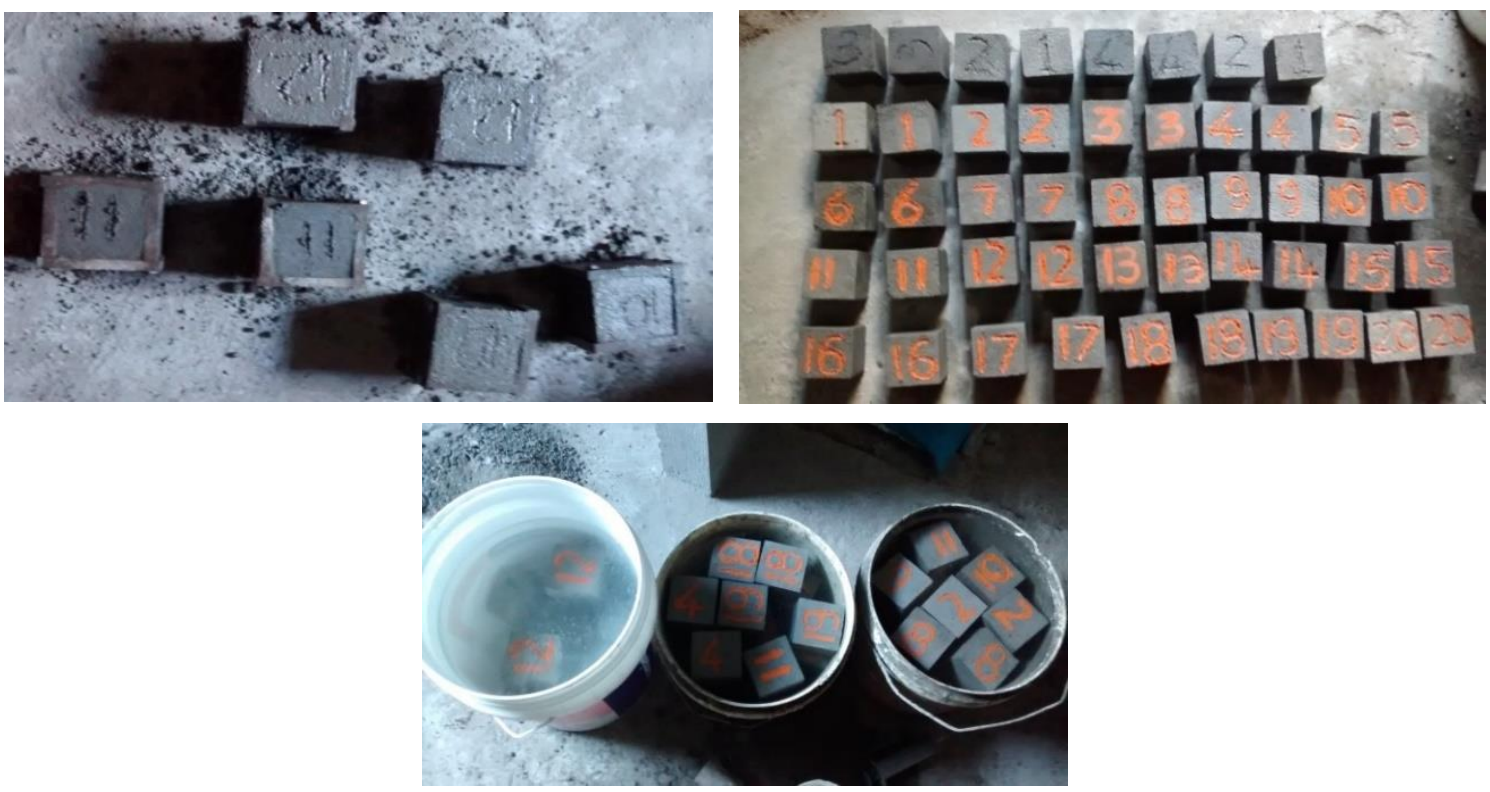

Figure 8. Casting and curing of specimens.

\section{2-8- Mortar Cube Compressive Strength}

Each case three cubes were tested for repeatability for all curing period. The cubes were tested on their sides without any adjustment packing between the cube and the steel plates of the compression testing machine. The load was applied steadily and uniformly, starting from zero at a rate of $35 \mathrm{~N} / \mathrm{mm}^{2} / \mathrm{min}$. The test set up is shown in Figure 9.
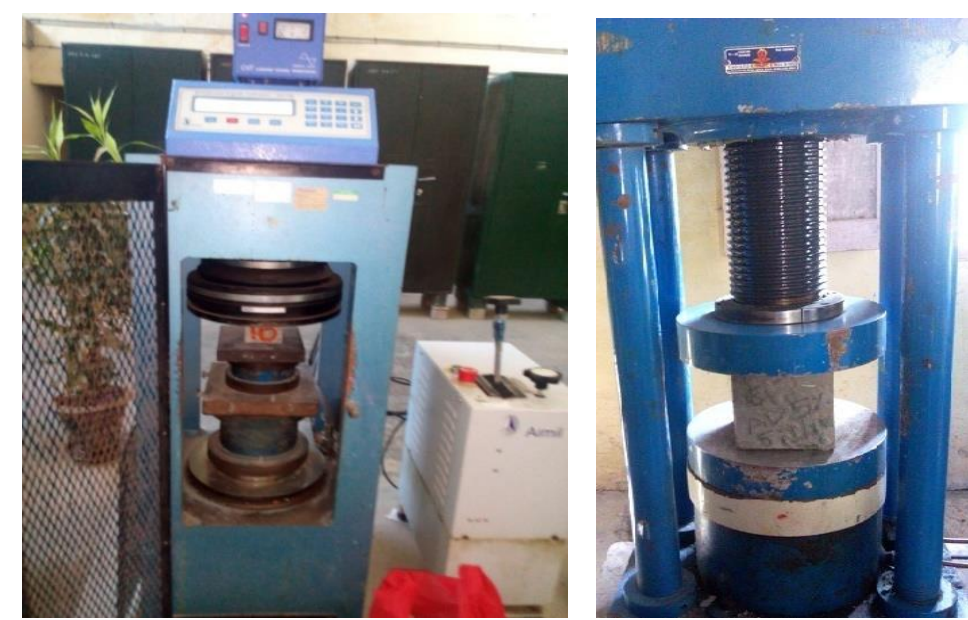

Figure 9. Mortar cube compressive strength test.

\section{2-9- Mortar Cube Compressive Strength Test Results}

Cast specimens were stored in water shall be tested immediately on removal from the water and while they are still in the wet condition. Surface water and grit shall be wiped off the specimens and any projecting fins removed. Then it is tested under compression as per the standards. The values obtained are shown in Table 7 to 10 .

Table 8. Mortar cube compressive strength test (OPC AF ES).

\begin{tabular}{ccccc}
\hline Sl. No & Alccofine $(\%)$ & $\mathbf{3}^{\text {rd }}$ Days $\left(\mathbf{N} / \mathbf{m m}^{2}\right)$ & $\mathbf{7}^{\text {th }}$ Days $\left(\mathbf{N} / \mathbf{m m}^{2}\right)$ & $\mathbf{2 8}^{\text {th }}$ Days $\left(\mathbf{N} / \mathbf{m m}^{2}\right)$ \\
\hline 1 & $\mathrm{AF}_{0}$ & 21.46 & 32.50 & 44.74 \\
2 & $\mathrm{AF}_{5}$ & 22.41 & 33.95 & 48.47 \\
3 & $\mathrm{AF}_{10}$ & 25.28 & 39.24 & 53.02 \\
4 & $\mathrm{AF}_{15}$ & 23.68 & 35.30 & 50.30 \\
5 & $\mathrm{AF}_{20}$ & 22.19 & 34.18 & 49.36 \\
\hline
\end{tabular}


Table 9. Compressive strength test for mortar cubes (OPC AF RS).

\begin{tabular}{|c|c|c|c|c|}
\hline Sl. No & Alccofine (\%) & $3^{\text {rd }}$ Days $\left(\mathrm{N} / \mathbf{m m}^{2}\right)$ & $7^{\text {th }}$ Days $\left(\mathrm{N} / \mathrm{mm}^{2}\right)$ & $28^{\text {th }}$ Days $\left(\mathrm{N} / \mathrm{mm}^{2}\right)$ \\
\hline 1 & $\mathrm{AF}_{0}$ & 20.33 & 30.40 & 41.38 \\
\hline 2 & $\mathrm{AF}_{5}$ & 23.80 & 33.62 & 42.86 \\
\hline 3 & $\mathrm{AF}_{10}$ & 26.77 & 36.39 & 47.21 \\
\hline 4 & $\mathrm{AF}_{15}$ & 24.34 & 34.64 & 45.23 \\
\hline 5 & $\mathrm{AF}_{20}$ & 22.16 & 32.73 & 43.81 \\
\hline
\end{tabular}

Table 10. Compressive strength test for mortar cube (PPC AF ES).

\begin{tabular}{ccccc}
\hline Sl. No & Alccofine $(\%)$ & $\mathbf{3}^{\text {rd }}$ Days $\left(\mathbf{N} / \mathbf{m m}^{2}\right)$ & $\mathbf{7}^{\text {th }}$ Days $\left(\mathbf{N} / \mathbf{m m}^{2}\right)$ & $\mathbf{2 8}^{\text {th }}$ Days $\left(\mathbf{N} / \mathbf{m m}^{2}\right)$ \\
\hline 1 & $\mathrm{AF}_{0}$ & 15.49 & 20.48 & 32.74 \\
2 & $\mathrm{AF}_{5}$ & 17.20 & 23.83 & 38.18 \\
3 & $\mathrm{AF}_{10}$ & 19.16 & 28.12 & 47.04 \\
4 & $\mathrm{AF}_{15}$ & 17.93 & 25.32 & 40.18 \\
5 & $\mathrm{AF}_{20}$ & 16.73 & 24.43 & 39.72 \\
\hline
\end{tabular}

Table 11. Compressive strength test for mortar cubes (PPC AF RS).

\begin{tabular}{ccccc}
\hline Sl. No & Alccofine $(\%)$ & $\mathbf{3}^{\text {rd }}$ Days $\left(\mathbf{N} / \mathbf{m m}^{2}\right)$ & $\mathbf{7}^{\text {th }}$ Days $\left(\mathbf{N} / \mathbf{m m}^{2}\right)$ & $\mathbf{2 8}^{\text {th }}$ Days $\left(\mathbf{N} / \mathbf{m m}^{2}\right)$ \\
\hline 1 & $\mathrm{AF}_{0}$ & 13.96 & 19.82 & 31.01 \\
2 & $\mathrm{AF}_{5}$ & 14.43 & 22.28 & 35.28 \\
3 & $\mathrm{AF}_{10}$ & 16.05 & 26.80 & 36.64 \\
4 & $\mathrm{AF}_{15}$ & 14.41 & 24.80 & 33.10 \\
5 & $\mathrm{AF}_{20}$ & 13.6 & 23.57 & 31.36 \\
\hline
\end{tabular}

\section{3- Results and Discussions}

\section{3-1- Mechanical Properties}

The strength on mortar cubes are determined based on the standard test procedure;

\section{3-1-1-Compression Test Results on Mortar Cubes $(\mathrm{OPC}+\mathrm{AF}+\mathrm{ES})$}

The results were obtained from the compressive strength of the mortar with various mix proportions are presented in the form of bar charts and graphs. The mortar cube compressive strength is gradually increased with respect to dosage of Alccofine and days of curing. It found that Alccofine 10\% of mortar mix gives the higher strength at all ages of days and also Indian Standard Sand (Ennore Sand) gives more compressive strength than the River Sand. Indian Standard Sand (Ennore Sand) gives better workability than the River Sand in the same WB ratio. Alccofine 10\% mortar mix given higher strength than other dosage of Alccofine alone as compared with control mortar cube by $17 \%$ and AF $15 \%$ slightly lesser than the AF10\%. Same kind of variation in all the ages of days for all the mixes (Figures 10 and 11).

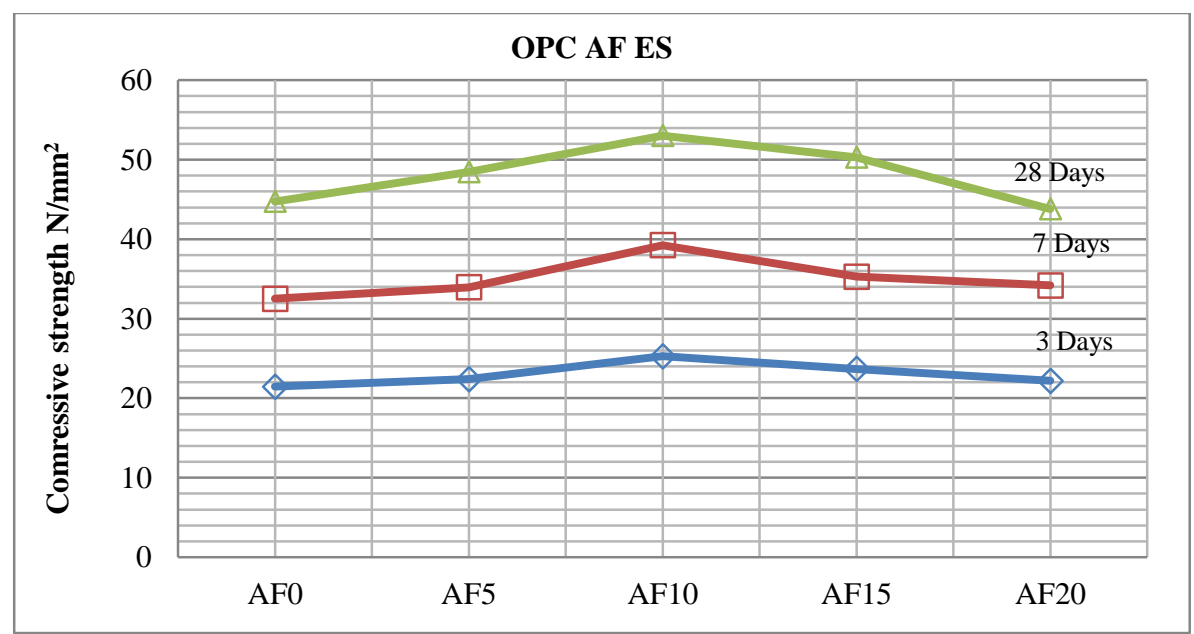

Figure 10. Compressive strength at all age of day. 


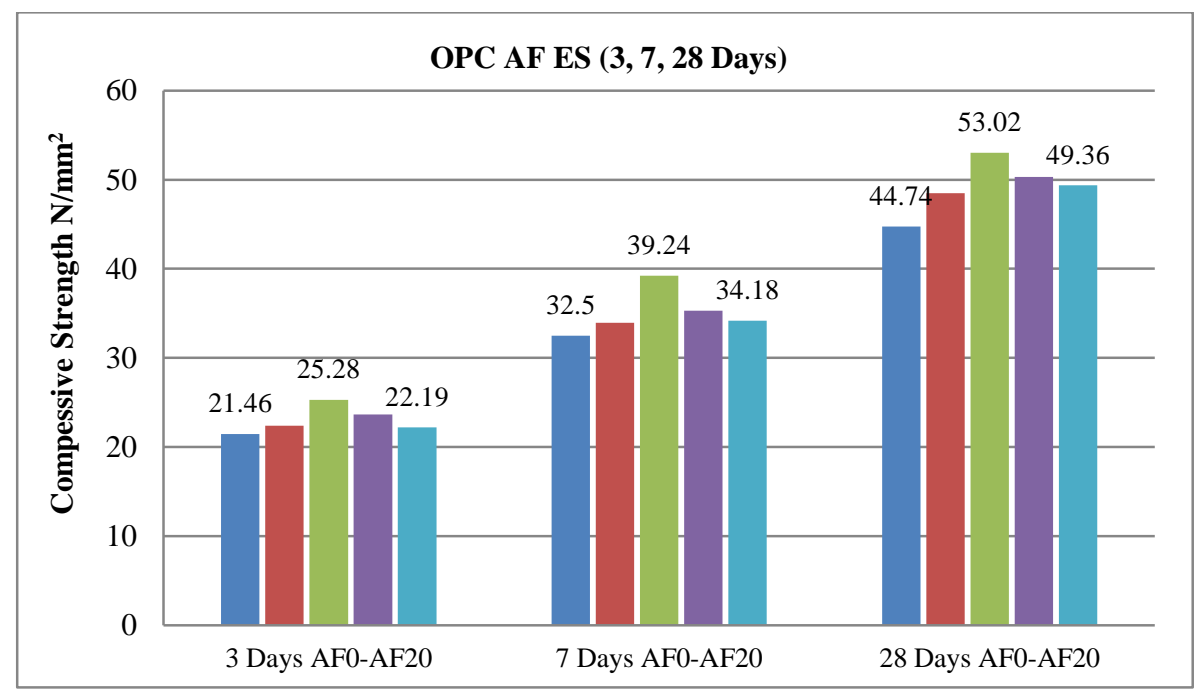

Figure 11. Comparative cube compressive strength at 3, 7, 28 days.

\section{3-1-2- Compression Test Results on Mortar Cubes $(\mathrm{OPC}+\mathrm{AF}+\mathrm{RS})$}

The mortar cube strength is gradually increased with the increase of days of curing. Alccofine $10 \%$ of mortar mix get the higher strength at all age of days. When compare the cube strength of river sand to Indian standard sand, the river sand gives little bit lower value than the Ennore sand in all age of days. AF 10\% mortar mix given higher strength than other dosages of AF alone as compared with control mortar cube by $13 \%$ (Figures 12 and 13).

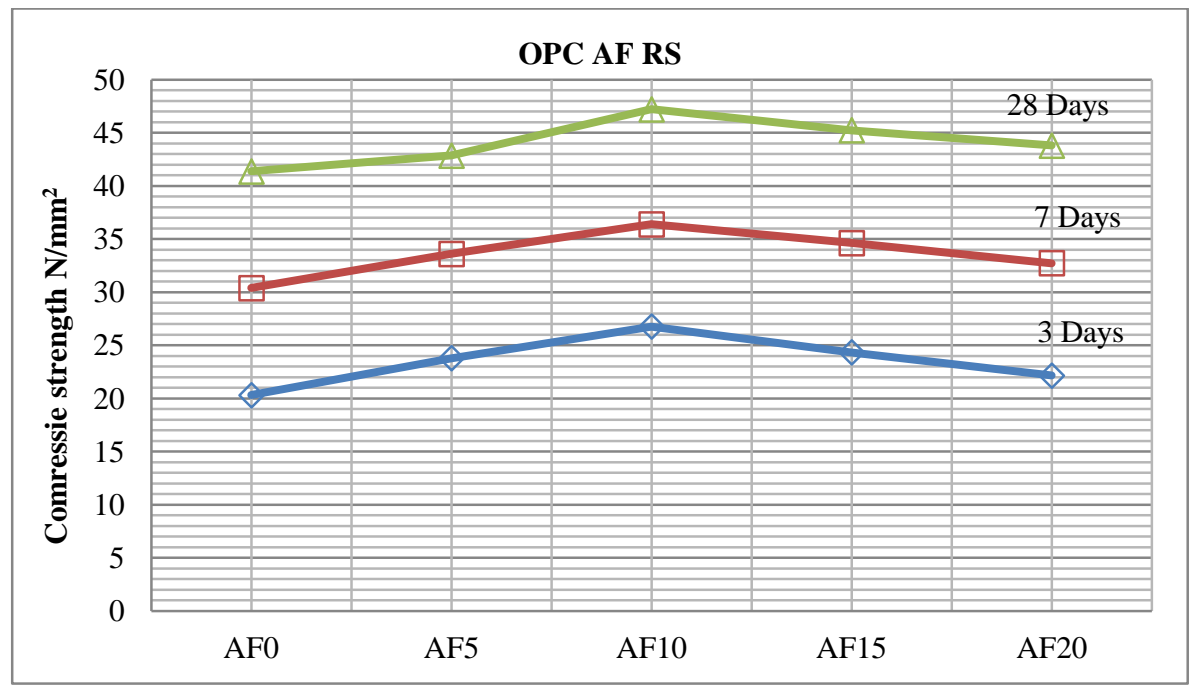

Figure 12. Mortar cube compressive strength at different age.

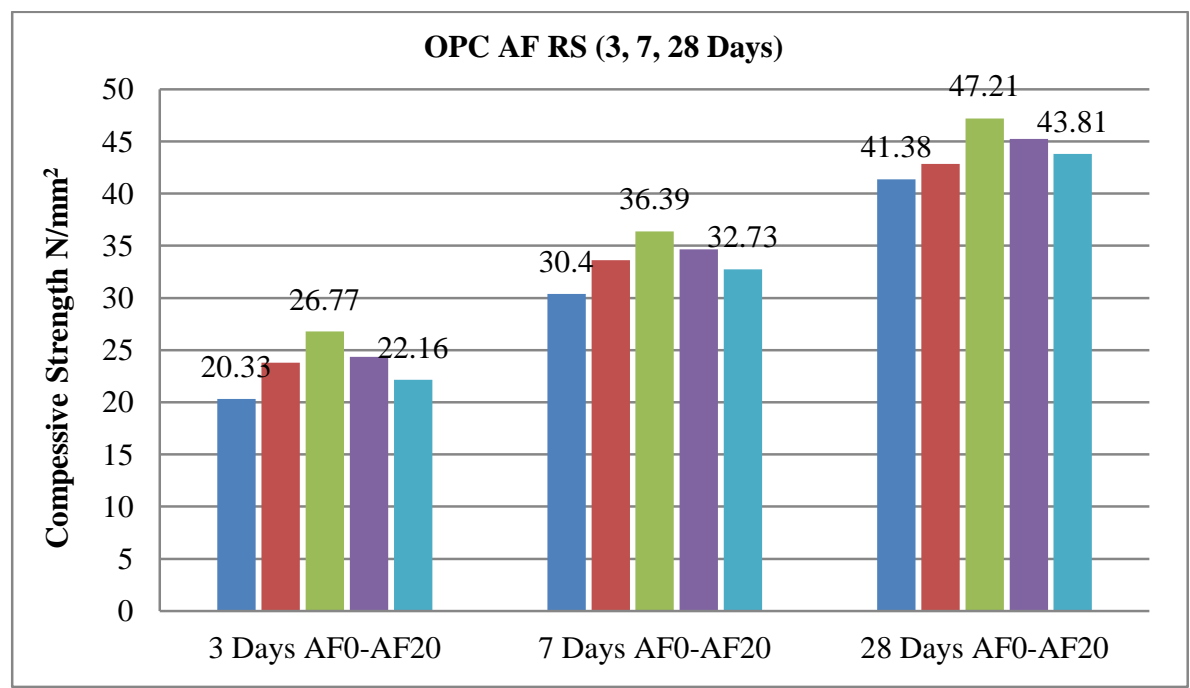

Figure 13. Mortar cube comparative compressive strength at the age of 3, 7, 28 day. 


\section{3-1-3- Comparative Compressive Strength at All Age of $\mathrm{OPC}+\mathrm{AF}+\mathrm{ES}+\mathrm{RS}$}

The cube strength results of various dosages at the different ages of $3^{\text {rd }}, 7^{\text {th }}, 28^{\text {th }}$ days are presented in table. The mortar cubes strength is gradually increased. The Alccofine 10\% mix get the excellent strength achievement within 3 days' strength is $19.16 \mathrm{~N} / \mathrm{mm}^{2}$.The results show that optimum $10 \%$ of Alccofine get the excellent result as compare with controlled mix and other percentage of Alccofine mix. Alccofine 10\% of mortar mix get the higher strength at all age of days. Indian Standard Sand (Ennore Sand) gives more compressive strength than the River Sand. Indian Standard Sand (Ennore Sand) gives good workability than the River Sand in the same WB ratio (Figure 14).

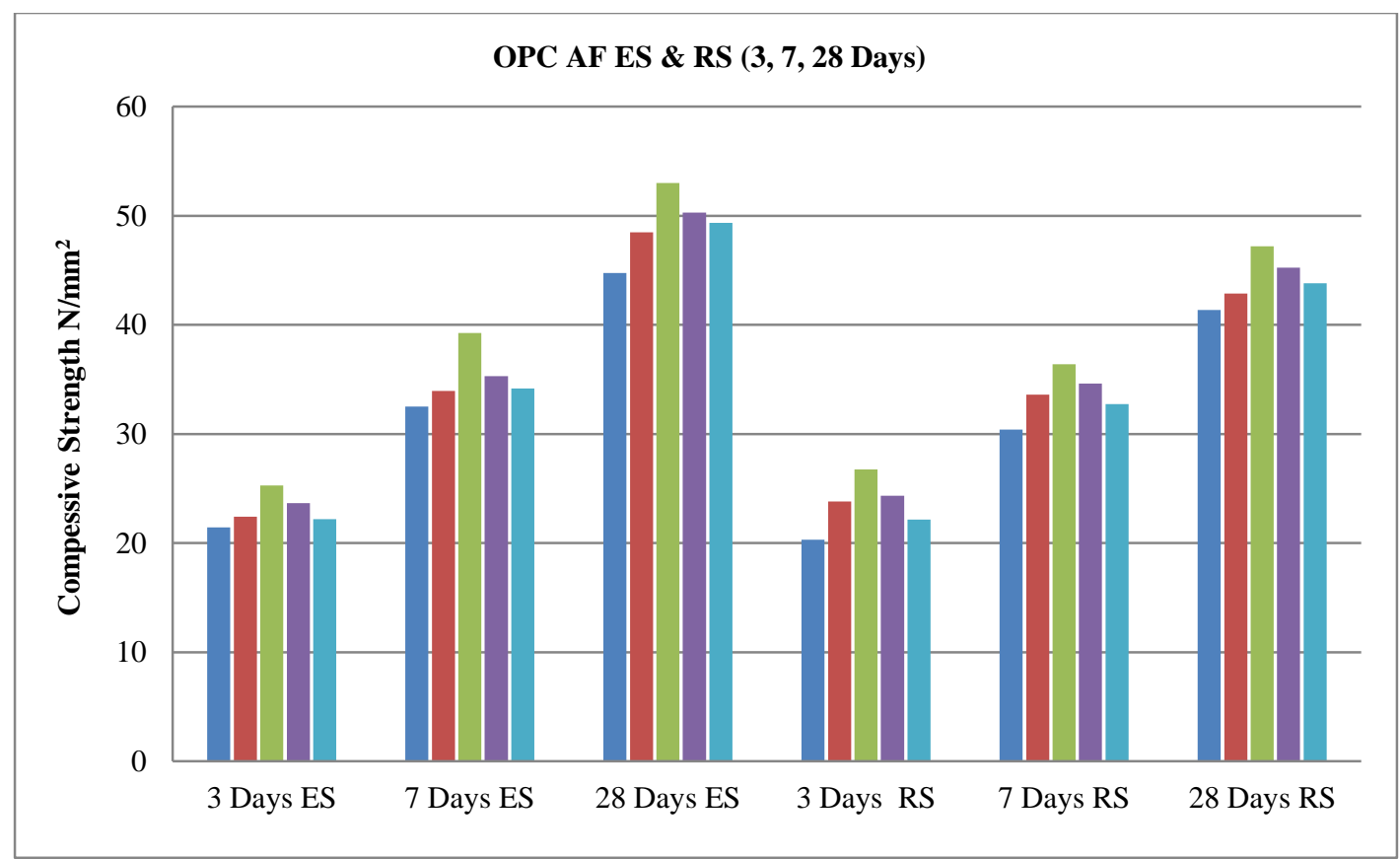

Figure 14. Mortar cube comparative compressive strength at all age of OPC AF ES \& RS.

\section{3-1-4-Compression test results on mortar cubes (PPC AF ES)}

Similarly, PPC combination results were obtained from the compressive strength of the mortar with various mix proportions are presented in the form of bar charts and graphs. The mortar cube compressive strength is gradually increased with respect to dosage of Alccofine and days of curing. It found that Alccofine 10\% of mortar mix gives the higher strength at all ages of days and also Indian Standard Sand (Ennore Sand) gives more compressive strength than the River Sand. Indian Standard Sand (Ennore Sand) gives better workability than the River Sand in the same WB ratio (Figure 15 and 16).

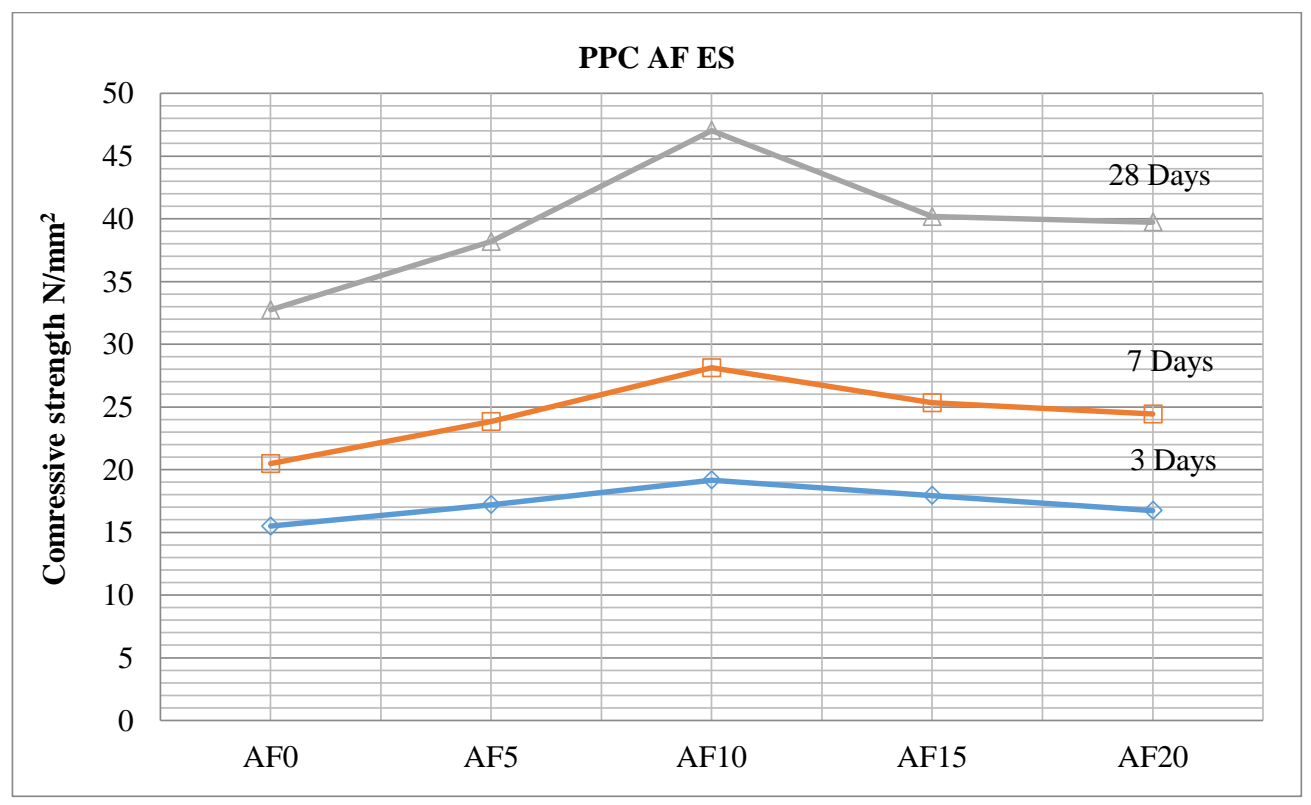

Figure 15. Mortar cube compression strength at different age. 


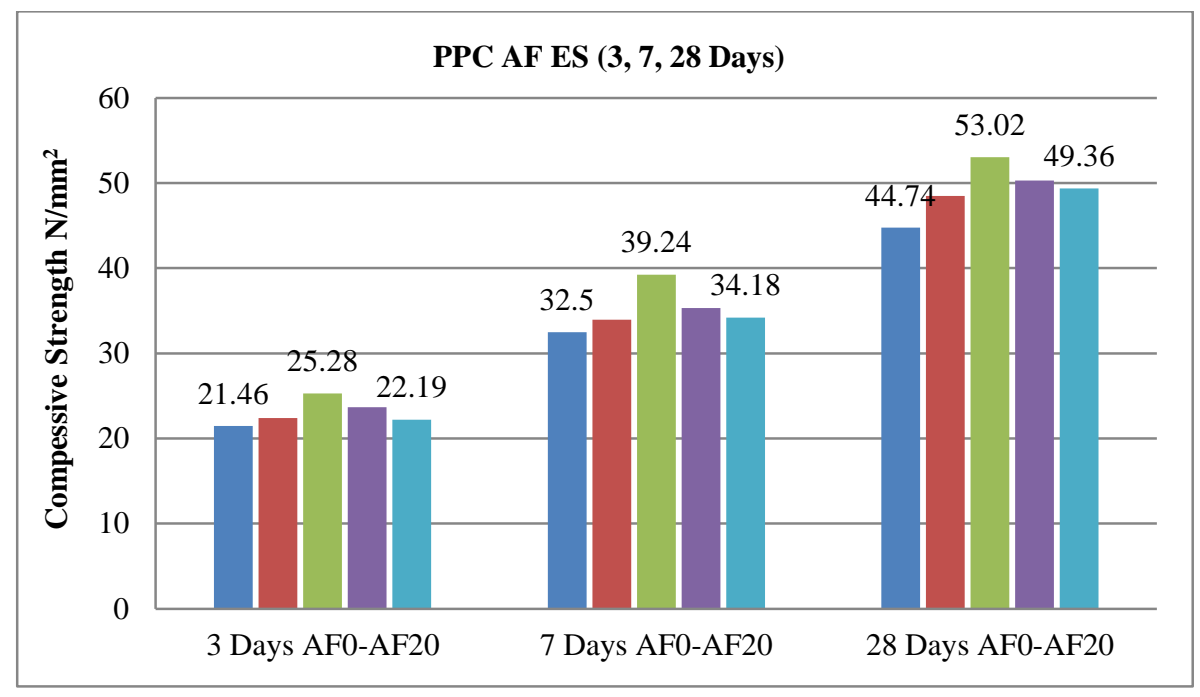

Figure 16. Mortar cube comparative compressive strength at the age of 3, 7, 28 days.

Compression test results on mortar cubes PPC $+\mathrm{AF}+\mathrm{RS}$ are shown in Figure 17 and 18. Alccofine 10\% of mortar mix gives the higher strength at all ages of days and also Indian Standard Sand (Ennore Sand) gives more compressive strength than the River Sand. Nearly 15\% increased compressive strength using river sand and ennore sand gives $30 \%$ increased compressive strength with respect to control mix. Comparative compressive strength at all ages of PPC AF ES $\&$ RS is shown in Figure 19. Total comparison of with respect to control mix at 28 days curing compressive strength for all mixes and all ages of cubes is shown in Figure 20.

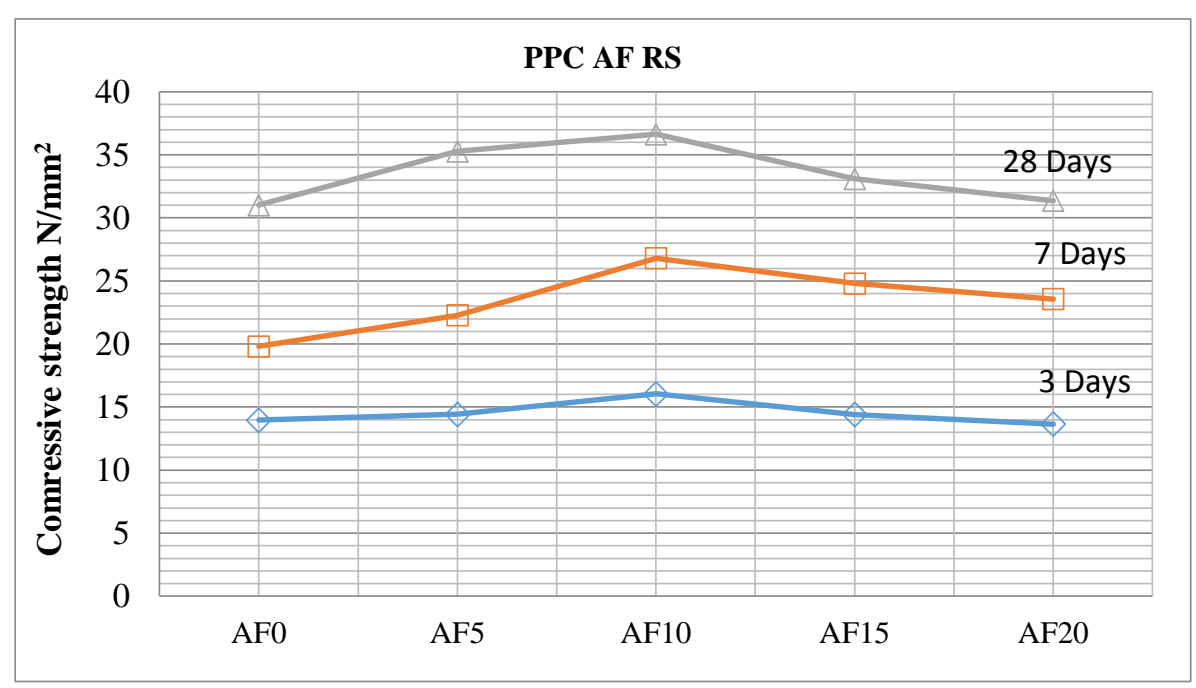

Figure 17. Mortar cube compression strength at all age of days.

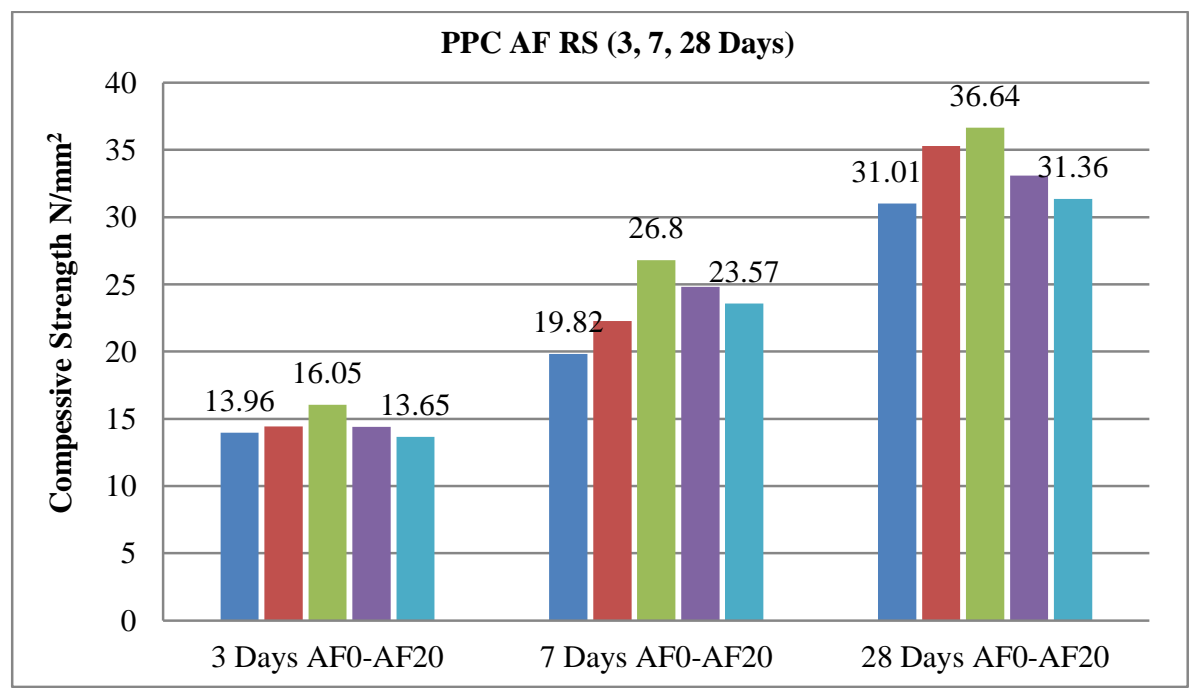

Figure 18. Mortar cube comparative compressive Strength at the age of 3,7,28 days. 


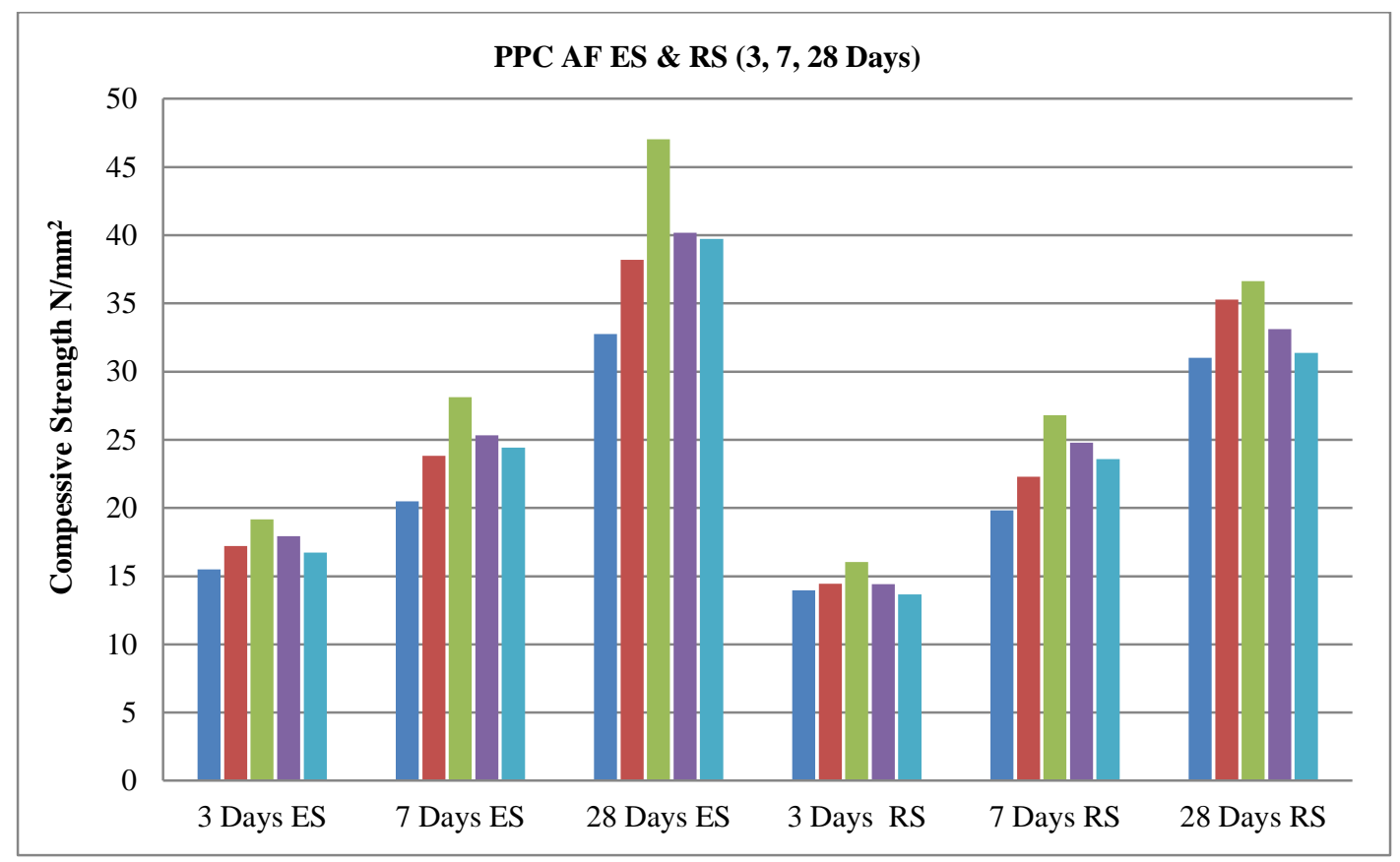

Figure 19. Mortar cube compressive Strength at all age of PPC AF ES \& RS.

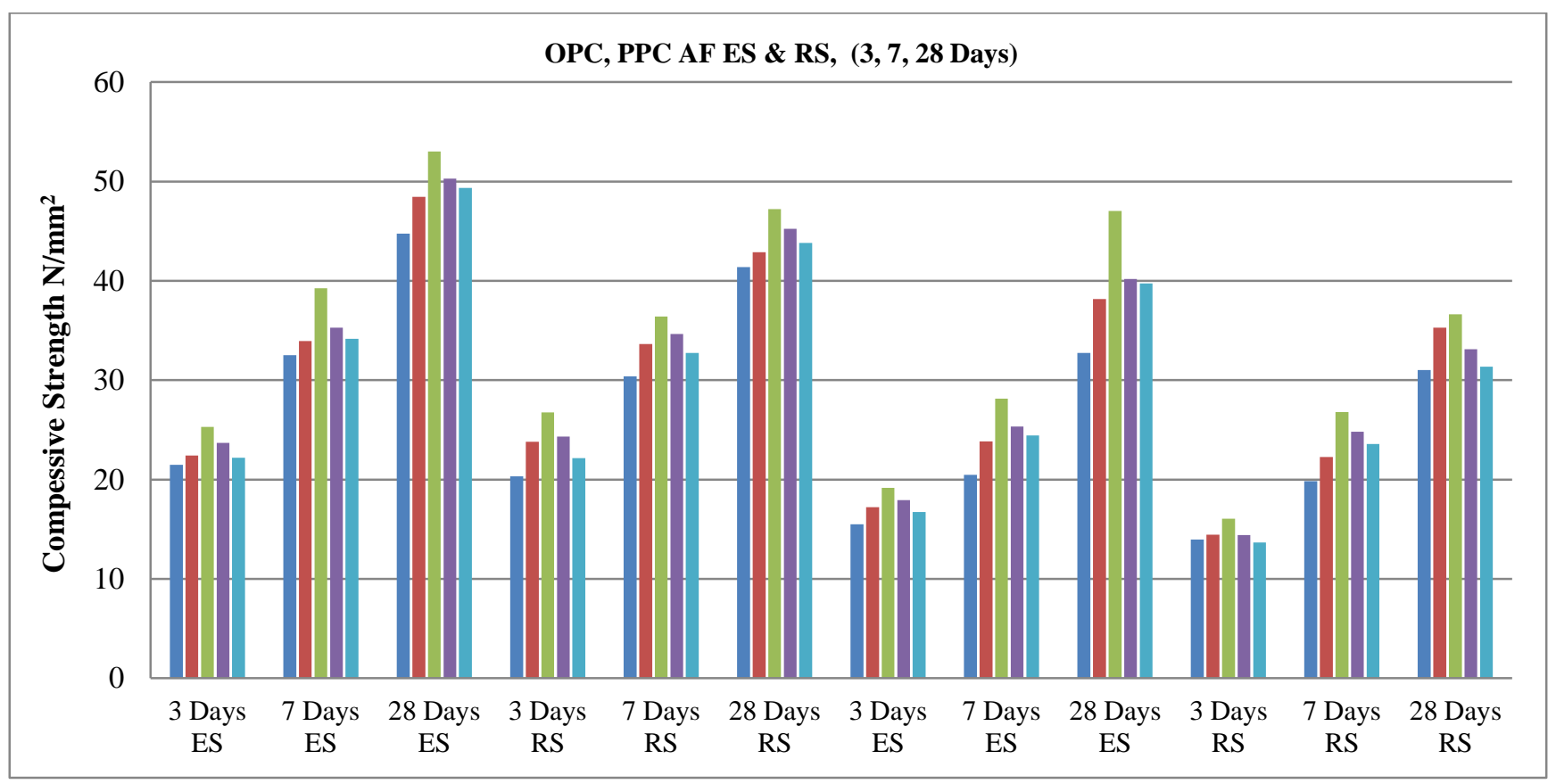

Figure 20. Total comparison of compressive strength at all age of OPC PPC AF ES \& RS.

\section{4- Conclusions}

In this study the effect of AL as supplementary cementitious materials of cement mortar cubes. Based on the detailed experimental investigations the following conclusions are drawn:

- Total twenty different combinations with Ordinary Portland Cement, Portland Pozzolana Cement, Ennore Sand, River Sand and Alccofine with different dosages were investigated in terms of compressive strength of cement mortar cubes.

- All the different combinations as a partial replacement of cement using alccofine.

- Among the different twenty combinations the maximum compressive strength of cement mortar cubes is achieved by using AL10\% (OPC AF ES) of the volume of cement is $53.12 \mathrm{~N} / \mathrm{mm}^{2}$.

- The optimum replacement of cement by the Alccofine is $10 \%$ of the volume of the cement. 
- OPC $\mathrm{AF}_{10} \mathrm{ES}$, OPC $\mathrm{AF}_{10} \mathrm{RS}$, PPC $\mathrm{AF}_{10} \mathrm{ES}$ and $\mathrm{PPC} \mathrm{AF}_{10} \mathrm{RS}$ give $16 \%, 13 \%, 30 \%$ and $15 \%$ increased compressive strength with respect to control cubes respectively.

- The cement replacement by $10 \%$ of Alccofine gives higher values of all other mixes. Alccofine incorporated mortar cubes almost $15 \%$ to $20 \%$ higher than the conventional cement concrete.

- The strength of cubes mainly depends upon the percentage of Alccofine based on its high pozzolanic nature to form a denser Calcium Silicate Hydrate (CSH) gel. Hence it exhibits the addition of alccofine proves that there is some significant contribution to cement in its strength.

- It is evident that the percentage of Alccofine is increased beyond 10\%, it acts as filler material for cement mortar cubes.

- Among all the mixes, OPC with Ennore Sand yields better results than other combinations.

- The Ennore Sand (ES) gives better results compared to River Sand (RS).

- It may be suggested to utilize the Alccofine material with cement after checking its durability studies.

\section{5- Declarations}

\section{5-1- Author Contributions}

Conceptualization, B.R. and S.J.; writing — original draft preparation, B.R. and S.J.; writing - review and editing, B.R. and S.J. All authors have read and agreed to the published version of the manuscript.

\section{5-2- Data Availability Statement}

The data presented in this study are available on request from the corresponding author.

\section{5-3- Funding}

The authors received no financial support for the research, authorship, and/or publication of this article.

\section{5-4- Conflicts of Interest}

The author declares that there is no conflict of interests regarding the publication of this manuscript. In addition, the ethical issues, including plagiarism, informed consent, misconduct, data fabrication and/or falsification, double publication and/or submission, and redundancies have been completely observed by the authors.

\section{6- References}

[1] Bansari Navinchandra Dave., Nikhil G Raval., Nilesh Hapaliya. "A Study on Effect of Alccofine on the Performance of the Concrete for Rigid Pavement Design and Analysis by Using Kenpave Software". International Journal of Advance Engineering and Research Development 3, no.1 (January 2016): 02-11. doi: 10.21090/ijaerd.030150.

[2] Srinivasreddy, K., S. Balamurugan. "Effect of Alccofine 1203 on Setting Times and Strength of Ternary Blended Geopolymer Mixes with Msand Cured at Ambient Temperature”. Romanian Journal of Materials 49, no. 4 (April 2019): 527-534.

[3] Kundanati, Rahul Raj, Tanmay Malpani, and V. Sairam. "Study on Mechanical Properties of Mortar Using Alccofine and Graphene Oxide.” Materials Today: Proceedings 22 (2020): 2431-2438. doi:10.1016/j.matpr.2020.03.369.

[4] Sagar, Bhanavath, and Sivakumar M.V.N. "Mechanical and Microstructure Characterization of Alccofine Based High Strength Concrete.” Silicon (January 4, 2021). doi:10.1007/s12633-020-00863-X.

[5] Haldar, Puja, and Somnath Karmakar. "An Experimental Study on Fatigue Property of Alccofine Based Crumb Rubber Concrete." Proceedings of the Institution of Civil Engineers - Engineering Sustainability (March 29, 2021): 1-13. doi:10.1680/jensu.20.00080.

[6] Jindal, Bharat Bhushan, Dhirendra Singhal, Sanjay K. Sharma, Deepankar K. Ashish, and Parveen Parveen. "Improving Compressive Strength of Low Calcium Fly Ash Geopolymer Concrete with Alccofine.” Advances in Concrete Construction 5, no. 1 (February 25, 2017): 17-29. doi:10.12989/acc.2017.5.1.17.

[7] Balamuralikrishnan, R., J. Saravanan. "Study on Bond Strength of Alccofine Based Normal and High Strength Concrete". Civil Engineering Journal 5, no.3 (March 2019):679-689. doi: 10.28991/cej-2019-03091278.

[8] Ashwini, K, and P Srinivasa Rao. "Evaluation of Correlation between Compressive and Splitting Tensile Strength of Concrete Using Alccofine and Nano Silica." IOP Conference Series: Materials Science and Engineering 1091, no. 1 (February 1, 2021): 012056. doi:10.1088/1757-899x/1091/1/012056.

[9] Ansari, U.S., I.M. Chaudhri., N.P Ghuge., and R.R. Phatangre. "High Performance Concrete with Partial Replacement of Cement by Alccofine and Fly ash". Indian Research Transaction 5, no.2 (August 2015): 19-23. 
[10] Boobalan, S.C., V. Aswin Srivatsav, A. Mohamed Thanseer Nisath, A. Pratheesh Babu, and V. Gayathri. "A Comprehensive Review on Strength Properties for Making Alccofine Based High Performance Concrete.” Materials Today: Proceedings (February 2021). doi:10.1016/j.matpr.2021.01.278.

[11] Patel, P.J., H.S. Patel. "Effect on Compressive and Flexural Strength of High - Performance Concrete Incorporating Alccofine and Fly ash”. International journal of Civil, Structural, Environmental and Infrastructure Engineering 3, no. 4 (April 2013): 109113.

[12] Reddy, P. Narasimha, and J. Ahmed Naqash. "Development of High Early Strength in Concrete Incorporating Alccofine and Non-Chloride Accelerator.” SN Applied Sciences 1, no. 7 (June 20, 2019). doi:10.1007/s42452-019-0790-z.

[13] Jindal, Bharat Bhushan. "Investigations on the Properties of Geopolymer Mortar and Concrete with Mineral Admixtures: A Review." Construction and Building Materials 227 (December 2019): 116644. doi:10.1016/j.conbuildmat.2019.08.025.

[14] Parveen, Dhirendra Singhal, M. Talha Junaid, Bharat Bhushan Jindal, and Ankur Mehta. "Mechanical and Microstructural Properties of Fly Ash Based Geopolymer Concrete Incorporating Alccofine at Ambient Curing." Construction and Building Materials 180 (August 2018): 298-307. doi:10.1016/j.conbuildmat.2018.05.286.

[15] Balamuralikrishnan, R., and Saravanan J. "Effect of Alccofine and GGBS Addition on the Durability of Concrete." Civil Engineering Journal 5, no. 6 (June 24, 2019): 1273-1288. doi:10.28991/cej-2019-03091331.

[16] Rajesh, Kumar S., Amiya K. Samanta, and Dilip K. Singha Roy. "An Experimental Study on the Compressive Strength of Alccofine with Silica Fume Based Concrete." Applied Mechanics and Materials 857 (November 2016): 36-40. doi:10.4028/www.scientific.net/amm.857.36.

[17] IS 650., "Specification for Standard Sand for Testing of Cement, CED 2: Cement and Concrete, Bureau of Indian Standards", New Delhi, India (May 1994).

[18] IS 8112., "Specification for 43 grade Ordinary Portland Cement, CED 2: Cement and Concrete, Bureau of Indian Standards", New Delhi, India (June 1998).

[19] IS 2386-3., "Methods of Test for Aggregate for Concrete, Bureau of Indian Standards”, New Delhi, India (April 1963).

[20] IS 383., "Specification for Coarse and Fine Aggregates from Natural Sources for concrete, Bureau of Indian Standards”, New Delhi, India, (June 1970). 